\title{
A case of chronic pancreatic insufficiency due to valproic acid in a child
}

\author{
Mary Anne Cooper MSc MD FRCPC ${ }^{1}$, Aubrey Groll MBChB FRCPLond FRCPC ${ }^{2}$
}

\begin{abstract}
MA Cooper, A Groll. A case of chronic pancreatic insufficiency due to valproic acid in a child. Can J Gastroenterol 2001;15(2):127-130. A 14-year-old child treated with valproic acid over several years for a seizure disorder developed abdominal pain with radiological evidence of acute pancreatitis. The association with valproic acid was not recognized, and the child continued to take the drug. The patient eventually developed steatorrhea and weight loss that improved with pancreatic enzyme replacement. Radiological evaluation showed an atrophic pancreas. Without evidence of other etiological factors, valproic acid by itself appeared to be the cause of chronic pancreatitis with exocrine pancreatic insufficiency in this patient.
\end{abstract}

Key Words: Chronic pancreatitis; Pancreatic insufficiency; Steatorrhea; Valproic acid

\section{Insuffisance pancréatique chronique due à l'acide valproïque chez un enfant}

RÉSUMÉ: Un enfant de 14 ans traité à l'acide valproïque depuis plusieurs années pour des troubles épileptiques est venu consulter pour des douleurs abdominales accompagnées de signes radiologiques de pancréatite aiguë. Le lien avec l'acide valprö̈que n'a pas été établi tout de suite et l'enfant a continué à prendre son médicament. Il a ensuite commencé à présenter de la stéatorrhée, puis à perdre du poids, mais un traitement de substitution des enzymes pancréatiques a corrigé la situation. L'évaluation radiologique a révélé une atrophie du pancréas. En l'absence d'autres facteurs étiologiques, l'acide valproïque a été jugé la seule cause possible de la pancréatite chronique, accompagnée d'insuffisance exocrine.
$\mathrm{V}$ alproic acid (VPA) is a short chain fatty acid used to treat a variety of seizure disorders (1). The most common side effect is transient alopecia (2). Hepatotoxicity, ranging from asymptomatic elevation of aminotransaminase levels to fulminant hepatitis, also occurs (3). Many cases of acute pancreatitis due to VPA have been reported (2,4-23). We report a case of chronic pancreatitis with exocrine pancreatic insufficiency that appears to have been caused by VPA.

\footnotetext{
${ }^{1}$ Sunnybrook and Women's College Health Sciences Centre, Sunnybrook Campus, University of Toronto, Toronto; ${ }^{2}$ Hotel Dieu Hospital, Queen's University, Kingston, Ontario

Correspondence and reprints: Dr MA Cooper, Sunnybrook and Women's College Health Sciences Centre, Sunnybrook Campus,

2075 Bayview Avenue, Suite HG64, Toronto, Ontario M4N 3M5. Telephone 416-480-6799, fax 416-480-5977

Received for publication August 23, 1999. Accepted November 26, 1999
} 


\section{CASE PRESENTATION}

A 14-year-old white boy born at 40 weeks' gestation developed a generalized tonic-clonic seizure disorder at two weeks of age. He had normal growth and attainment of developmental milestones but required treatment for the seizures. He responded poorly to phenobarbital, carbamazepine and phenytoin, either alone or in combination. VPA was given for the first time before the patient was five years of age but was discontinued because it was 'not tolerated'. There was no detailed documentation of this intolerance or of other medications used. There were no biochemical data from that time. VPA was reinstituted in 1987 at age five years. The drug was tolerated well initially at $500 \mathrm{mg} /$ day (with a measured drug level of $300 \mu \mathrm{mol} / \mathrm{L}$, therapeutic range of 350 to $700 \mu \mathrm{mol} / \mathrm{L}$; the patient's weight was not documented). When the drug dose was increased to $1500 \mathrm{mg} /$ day (no drug level available), nausea and vomiting developed, and VPA was discontinued again. Because best control of his seizures had been obtained with VPA, it was reinstituted as monotherapy in 1991 when the patient was nine years of age, and he was maintained on $1000 \mathrm{mg} /$ day $(27 \mathrm{mg} / \mathrm{kg})$ without incident. The patient had demonstrated a learning disability in school, particularly in his reading skills, but was able to communicate clearly verbally. In April 1994 (at 11 years of age) he presented with complaints of gradual onset left upper quadrant pain with nausea and vomiting. He was diagnosed with viral gastroenteritis at his local emergency department. Because these symptoms persisted over several months, an abdominal ultrasound was done in August 1994, revealing an enlarged pancreas. Serum amylase or lipase levels from that time were not documented, but acute pancreatitis was diagnosed based on these radiological findings. No therapeutic intervention was undertaken, and he remained on VPA. By October 1994, the abdominal pain had resolved, but he described pale, loose, foul-smelling stools with 'oil in water' suggestive of steatorrhea, having four to five such bowel movements daily. Over January and February 1995, he lost $7 \mathrm{~kg}$. He was referred to the authors' centre in March 1995; he was admitted for investigation and was tapered off the VPA. He had no history of significant abdominal trauma and no respiratory symptoms. There was no family history of pancreatitis, celiac disease or cystic fibrosis.

On admission, he weighed $37.2 \mathrm{~kg}$. Physical examination was normal. The complete blood count, peripheral smear, serum B12, folic acid, amylase, total serum protein and albumin, calcium, aspartate aminotransferase, alanine aminotransferase and erythrocyte sedimentation rate were normal. Serum lipase level was not measured. Seventy-two hour fecal fat excretion was markedly abnormal at $47 \mathrm{~g} /$ day (normal less than $5.5 \mathrm{~g} /$ day). The serum trypsinogen level was low at $13.1 \mathrm{ng} / \mathrm{mL}$ (normal 16.9 to $46.5 \mathrm{ng} / \mathrm{mL}$ ). The pancreas was atrophic on ultrasound, and there was no evidence of cholelithiasis. Computed tomography confirmed these findings and failed to identify the tail. No calcification was noted, and no pseudocysts were present. Endoscopic retrograde cholangiopancreatography demon- strated a narrowed, shortened pancreatic duct without evidence of pancreas divisum. The common bile duct was normal. A small bowel biopsy was normal. A secretin test was attempted, but the tube failed to enter the duodenum. A chest $\mathrm{x}$-ray showed peribronchial thickening. Repeated sweat chloride tests were normal, and results of molecular genetic testing for the 10 most common mutations associated with cystic fibrosis were negative.

Chronic pancreatitis with exocrine pancreatic insufficiency was diagnosed, and the patient was treated with pancreatic enzyme replacement. Carbamazepine was started instead of VPA for the seizure disorder. During the next year, his weight increased from $37 \mathrm{~kg}$ to $54 \mathrm{~kg}$. The patient has remained well on pancreatic enzyme replacement. Repeat abdominal ultrasonography has confirmed persistent pancreatic atrophy. Seventy-two hour fecal fat testing has repeatedly demonstrated steatorrhea when the patient has been off enzyme replacement ( $31.8 \mathrm{~g} /$ day to $33.5 \mathrm{~g} /$ day), with complete correction when on enzyme therapy ( $4.5 \mathrm{~g} /$ day). Any reduction in enzyme replacement therapy has led to loose bowel movements, typical of steatorrhea. His blood glucose level has remained within the normal range. He has never developed any respiratory symptoms.

\section{DISCUSSION}

Pancreatitis can be difficult to diagnose. In its acute form, the physician must rely on clinical suspicion with supportive biochemical and radiological evidence. It is with hindsight that we believe that this patient demonstrated acute pancreatitis in April 1994. His clinical condition was congruous with such a diagnosis (24), as was his abdominal ultrasound, although neither finding was specific. These ultrasound findings, however, are frequently found in children with acute pancreatitis $(13,25)$. This patient's evolution to chronic pancreatitis with pancreatic insufficiency is easier to document. He clearly had clinical steatorrhea corrected by pancreatic enzyme replacement with an atrophic gland documented radiologically by several modalities. Furthermore, the patient's serum trypsinogen level was low, which is a relatively specific indicator of loss of exocrine pancreatic function (26-28).

Chronic pancreatitis in children is most often due to cystic fibrosis; however, up to $30 \%$ of cases may be due to drugs (2). The present patient underwent repeated tests for cystic fibrosis, and results of clinical, biochemical and genetic analyses were negative. Although the number of mutations associated with cystic fibrosis is in the hundreds, in the white population, the 10 most common mutations measured account for almost $80 \%$ of cases (The Hospital for Sick Children, Molecular Genetics Laboratory, Toronto, Ontario; personal communication). The negative result in this situation supported the other findings. He had normal calcium and lipid levels. There was no family history of chronic pancreatitis to suggest a hereditary condition. His nutritional status was adequate (demonstrated by a normal growth curve [not shown]) until the onset of symptoms. There was no evidence of biliary tract stone disease or biliary tract 
anatomical abnormalities. There was no history of trauma, and he had no other systemic illnesses (other than the seizure disorder) or infections. This patient did not exhibit the extrapancreatic abnormalities of Schwachman syndrome (29).

VPA was introduced in 1978 for the management of seizures (1). It is known to cause transient, usually mild, nausea and vomiting, abdominal cramps, diarrhea, weight gain, alopecia and hyperammonemia (2). It rarely causes hepatitis in either a dose-dependent manner with a rise in aminotransaminase levels or an idiopathic fulminant form causing death (3). The first case of acute pancreatitis due to VPA was reported in 1979 (4). Since then, 55 cases have been reported in the literature $(2,4-23)$. The patients have ranged from one to 65 years of age and have developed pancreatitis after using VPA from six days to 14 years. Most cases have occurred with serum VPA levels in the therapeutic range of 30 to $60 \mathrm{mg} / \mathrm{kg} /$ day, but values have ranged from 25 to $75 \mathrm{mg} / \mathrm{kg} /$ day. Such variation has precluded the use of serum levels of VPA for screening patients at risk of pancreatitis. In one study, frequent transient increases in amylase levels were noted with the institution of VPA but were not predictive of pancreatitis (30).

There have been four deaths due to VPA-induced pancreatitis $(8,11,14,16)$, all from the initial acute attack. Many other patients, however, have been 'rechallenged' with VPA after resolution of an episode of acute pancreatitis before it was recognized that VPA was the cause. All but one experienced recurrent pancreatitis, which again resolved without sequelae upon cessation of the drug $(2,4$ $6,10)$. One patient is reported to have had 33 relapses of acute pancreatitis over an eight-year period, recovering from each episode with conservative therapy despite continued VPA use (11). One patient did not develop recurrent pancreatitis or deteriorate when VPA was maintained during and after resolution of an episode of acute pancreatitis (10).

\section{REFERENCES}

1. Sherard ES, Steinman GS, Couri D. Treatment of childhood epilepsy with valproic acid: Results of the first 100 patients in a 6-month trial. Neurology 1980;30:31-5.

2. Parker PH, Helinek GL, Gishan FK, Greene HL. Recurrent pancreatitis induced by valproic acid. Gastroenterology 1981;80:826-8.

3. Gram L, Bentsen KD. Valproate: An updated review. Acta Neurol Scand 1985;72:129-39.

4. Camfield PR, Bagnell P, Camfield CS, Tibbles JAR. Pancreatitis due to valproic acid. Lancet 1979;i:1198-9. (Lett)

5. Batalden PB, Van Dyne BJ, Cloyd J. Pancreatitis associated with valproic acid therapy. Pediatrics 1979;64:520-2.

6. Coulter DL, Allen RJ. Pancreatitis associated with valproic acid therapy for epilepsy. Ann Neurol 1980;7:92. (Lett)

7. Sasaki M, Tonoda S, Aoki Y, Katsumi M. Pancreatitis due to valproic acid. Lancet 1980;i:1196. (Lett)

8. Murphy MJ, Lyon LW, Taylor JW, Mitts G. Valproic acid associated pancreatitis in an adult. Lancet 1981;i:41-2. (Lett)

9. Ng JYK, Disney APS, Jones TE, Purdie G. Acute pancreatitis and sodium valproate. Med J Aust 1982;2:362. (Lett)

10. Callaghan N, O'Hare J, O’Driscoll D, O’Neill B, Daly M. Comparative study of ethosuximide and sodium valproate in the treatment of typical absence seizure (petit mal). Dev Med Child Neurol 1982;24:830-6.
There is only one previously reported case of chronic pancreatic insufficiency associated with VPA therapy - a 25-year-old man on combination therapy of VPA and carbamazepine for seizures related to cranial trauma (31). After 10 years of therapy, he developed abdominal pain with nausea and vomiting on a monthly basis over two to three years. He was well between episodes of pain. There was no interruption of his therapy. He then developed pancreatic calcification with pancreatic insufficiency documented by abnormal pancreolauryl test results, amino acid consumption and glucose tolerance tests.

Recent models of pancreatitis have focused on the role of oxidative stress as an etiological mechanism $(17,18,32$ 34). It is thought that a decrease in protective antioxidants or an increase in free radicals may initiate a diversion of pancreatic enzyme activity into the pancreatic parenchyma by disruption of acinar cell exocytosis. Persistent oxidative stress may allow this process to continue until the organ is 'burnt out' and the patient has passed into a phase of chronic disease, with either overt or subclinical pancreatic dysfunction (32). Drugs clearly can be a source of such oxidative stress. VPA specifically has been shown to reduce free radical scavenger enzyme activity. This has been postulated as the mechanism for inducing the well described acute pancreatitis or hepatotoxicity reactions (35). Our patient was taking VPA before and throughout his probable acute pancreatitis. Because he continued to take the drug, the oxidative stress was not relieved and his clinical condition progressed to chronic pancreatitis, following the pathophysiological model proposed by Braganza (32).

Without another etiological factor identified, we believe that VPA caused this patient's pancreatic disease, having caused acute pancreatitis, which, when continued in the face of an unrecognized association with pancreatic disease, progressed to chronic pancreatitis with exocrine pancreatic insufficiency.

11. Williams LHP, Reynolds RP, Emery JL. Pancreatitis during sodium valproate treatment. Arch Dis Child 1983;58:543-4.

12. Wyllie E, Wyllie R, Cruse RP, Erenberg G, Rothner AD. Pancreatitis associated with valproic acid therapy. Am J Dis Child 1984;138:912-4.

13. Rosenberg HK, Ortega W. Hemorrhagic pancreatitis in a young child following valproic acid therapy. Clin Pediatr 1987;26:98-101.

14. Lott JA, Bond LW, Bobo RC, McClung HJ, Murray RD. Valproic acid-associated pancreatitis: Report of three cases and a brief review. Clin Chem 1990;36:395-7.

15. Binek J, Hany A, Heer M. Valproic-acid-induced pancreatitis. J Clin Gastroenterol 1991;13:690-3.

16. Ford DM, Portman RJ, Lum GM. Pancreatitis in children on chronic dialysis treated with valproic acid. Pediatr Nephrol 1990;5:259-61.

17. Asconape JJ, Penry JK, Driefuss FE, Riela A, Mirza W. Valproateassociated pancreatitis. Epilepsia 1993;34:177-83.

18. Talwar D. Valproate-associated acute pancreatitis in a child with neuronal ceroid lipofuscinosis. J Child Neurol 1994;9:36-7.

19. Evans RJ, Miranda RN, Jordan J, Krolikowski FJ. Fatal acute pancreatitis caused by valproic acid. Am J Forensic Med Pathol 1995;16:62-5.

20. Tobias JD, Capero C, Sims P, Holcomb GW. Necrotizing pancreatitis after 10 years of therapy with valproic acid. Clin Pediatr (Phila) 1995;34:446-8. 


\section{Cooper and Groll}

21. Morevias Plaza M, Rodriguez Goyanes G, Cuina L, Alonso R. On the toxicity of valproic-acid. Clin Nephrol 1999;51:187-9.

22. Buzar RD, Fireston D, Thomas M, Dabovsky SL. Valproateassociated pancreatitis and cholecystitis in six mentally retarded adults. J Clin Psychiatry 1995;56:529-32.

23. Riikonen R. Misdiagnosis of pancreatitis during valproate treatment in gastroesophageal reflux. Arch Dis Child 1996;75:355. (Lett)

24. Jordan SC, Ament ME. Pancreatitis in children and adolescents. J Pediatr 1977;91:211-6.

25. Siegel MJ, Swit CJ. Pancreatic emergencies. Radiol Clin North Am 1997;35:815-30.

26. Goldberg DM, Durie PR. Biochemical tests in the diagnosis of chronic pancreatitis and in the evaluation of pancreatic insufficiency. Clin Biochem 1993;26:253-75.

27. Steinberg WM, Anderson KK. Serum trypsinogen in diagnosis of chronic pancreatitis. Dig Dis Sci 1984;29:988-93.

28. Steinberg WM, Goldstein SS, Davis ND, Anderson KK, Shamma'a JM. Predicting value of a low serum trypsinogen. Dig Dis Sci 1985;30:547-51.
29. Mack DR, Forstner GG, Wilschanski M, Freedman MH, Durie PR. Schwachman syndrome: exocrine pancreatic dysfunction and variable phenotypic expression. Gastroenterology 1996;111:1593-602.

30. Bale JF, Gray PE, Madsen JA. Monitoring of serum amylase levels during valproic acid therapy. Am J Forensic Med Pathol 1995;16:62-5.

31. Pezzilli R, Billi P, Melandri R, Broccoli PL, Fontana G. Anticonvulsant-induced chronic pancreatitis. A case report. Ital J Gastroenterol 1991;24:245-6.

32. Braganza JM. The pathogenesis of chronic pancreatitis. Q J Med 1996;89:243-50.

33. Uden S, Acheson DW, Reeves J, et al. Antioxidants, enzyme and induction, and chronic pancreatitis. Eur J Clin Nutr 1988;42:561-9.

34. Sanfey H, Bulkley GB, Cameron JL. The role of oxygen-derived free radicals in the pathogenesis of acute pancreatitis. Ann Surg 1984;200:405-13.

35. Pippenger CE, Meng X, VanLente J, Rothner AD. Valproate therapy depresses free radical scavenging enzyme activity: A probable mechanism for induction of acute pancreatitis or hepatotoxicity. Neurology 1989;39:214. (Abst) 


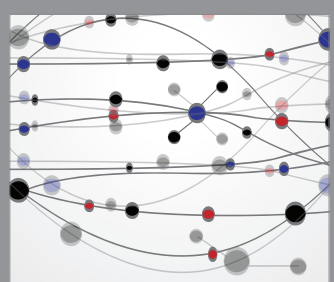

The Scientific World Journal
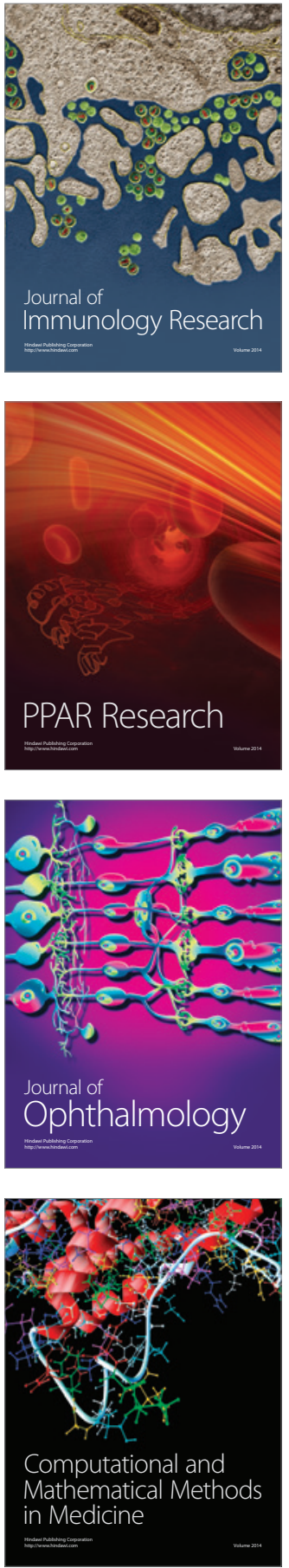

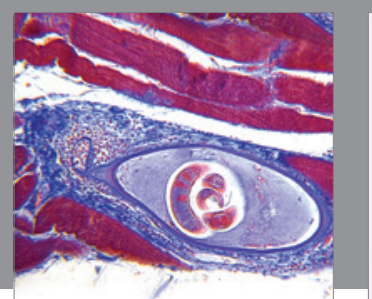

Gastroenterology Research and Practice

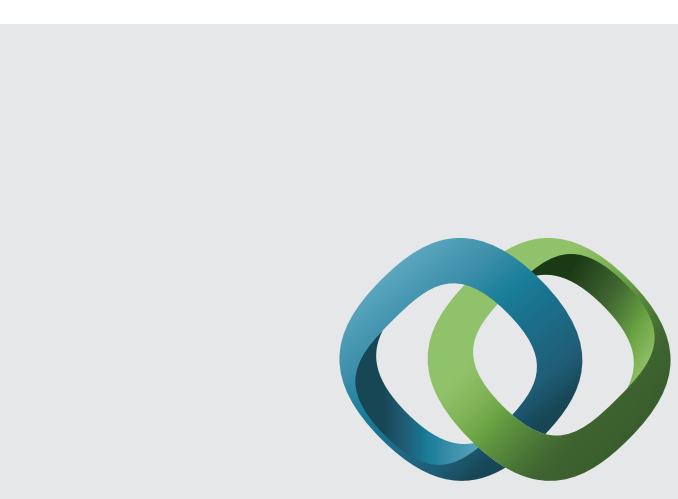

\section{Hindawi}

Submit your manuscripts at

http://www.hindawi.com
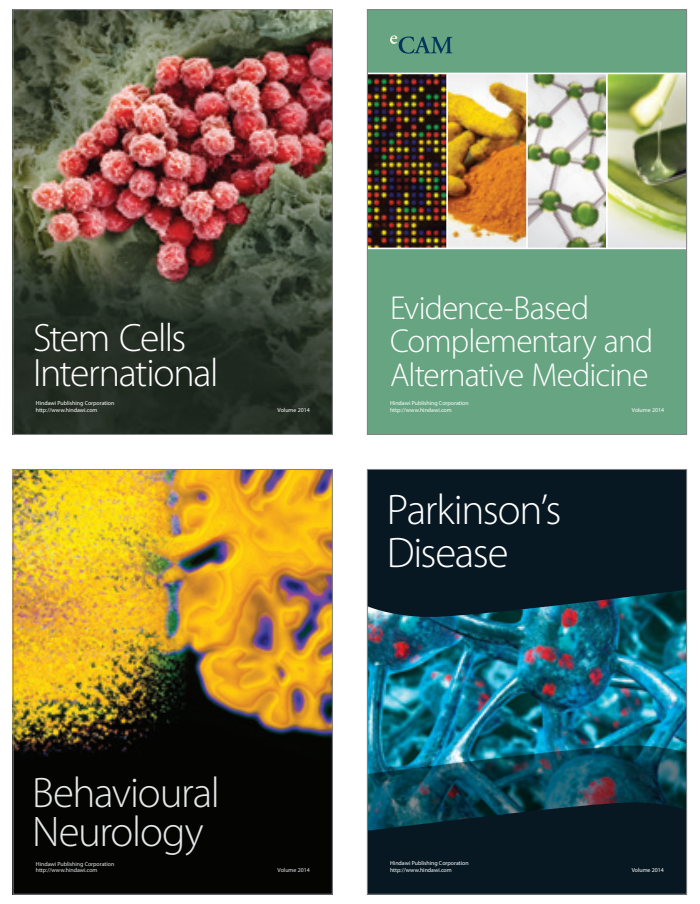
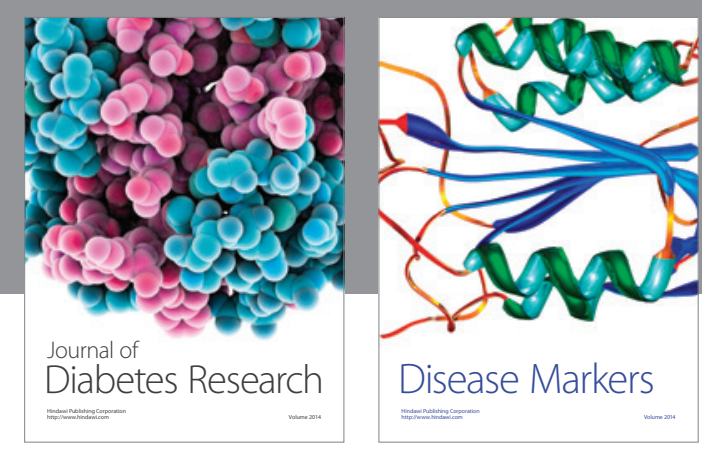

Disease Markers
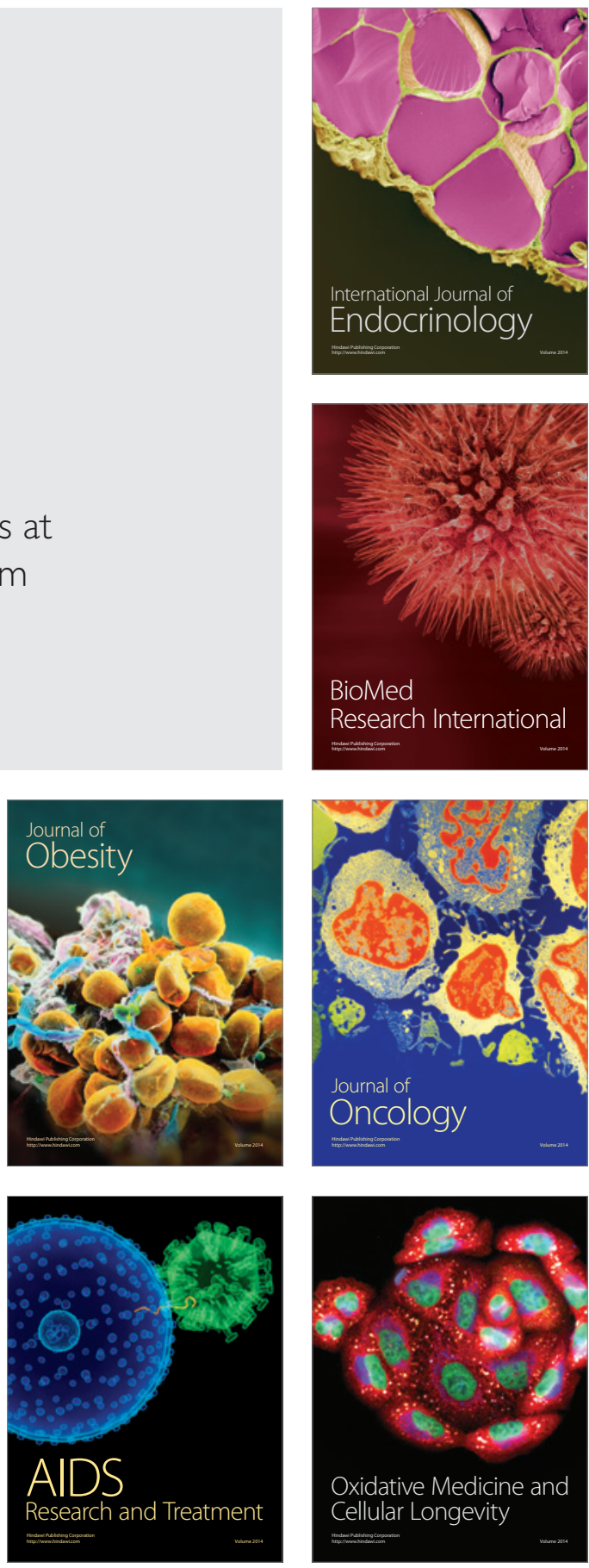